\title{
Islamic Habituation in Growing Students' Social Behavior
}

\author{
Baryanto, Syaiful Bahri, Irwan Fathurrochman, Alamsyahril
}

\begin{abstract}
This qualitative research aimed at revealing the habituation of Islamic values in MAN Rejang Lebong. This research used observation, interview, and documentation as instruments. The results showed that the school actualizes reciting the Qur'an before class begins, reciting prayer, reciting salawat, reading asmaul husna, praying duha and zuhur in congregation, applying the five $S$ (senyum, salam, sapa, sopan, santun), Friday prayers, Friday safaris, Friday morning cults, Friday charities and clean Friday and the implementation of religious activities routinely carried out by school principals using strategies in familiarizing religious activities, religious routine activities continuously. So it can cultivate religious social behavior such as the honest discipline of provident living helps be flexible in association and. As for the obstacles to performing the routine of religious activity, there is still a lack of motivation in students, so a small proportion of students are still less active or frequently latent when engaging in activities.
\end{abstract}

Keywords: Islamic Values, Principals Management, State Islamic High School Students

\section{INTRODUCTION}

The actual problems currently include the phenomenon of students engaging in free sex before marriage in Indonesia [19] [29] [38] drug abuse [32] Fight between students [20]. In accordance with the problems above, we conclude that the situation of students in Indonesia experiences social degradation or erosion of social values that are quite sharp.

To overcome the problem above, we conducted research in the context of tackling student delinquency in Indonesia, it is necessary to have a mental revolution as explained in the article [22], in this case, we conducted a study entitled Islamic Routines in Fostering Student Social Behavior at MAN Rejang Lebong. Preliminary survey results show that the coaching of students with parents, family, and teachers, in this case, Islamic Religious Education teachers (al-Quran Hadith, creed, fiqh, SKI, kalam subject and Arabic) in MAN Rejang Lebong. MAN Rejang Lebong teacher provides guidance to students through routine religious activities in

Revised Manuscript Received on December 30, 2019.

* Correspondence Author

Baryanto, State Institute of Islamic Studies (IAIN) Curup, Curup, Indonesia. Email: baryanto@iaincurup.ac.id

Syaiful Bahri, State Institute of Islamic Studies (IAIN) Curup, Curup, Indonesia. Email: syaiful@iaincurup.ac.id

Irwan Fathurrochman, State Institute of Islamic Studies (IAIN) Curup, Curup, Indonesia. Email: irwan@iaincurup.ac.id

Alamsyahril, BKPSDM Lubuklinggau, Lubuklinggau, Indonesia. Email: alamsyahril@lubuklinggaukota.go.id

(C) The Authors. Published by Blue Eyes Intelligence Engineering and Sciences Publication (BEIESP). This is an open access article under the CC BY-NC-ND license (http://creativecommons.org/licenses/by-nc-nd/4.0/) order to foster morals and foster religious social behavior of students and be practiced in daily life in collaboration with parents and the community) [7] [12] [43]. This activity is inseparable from the role of the principal in actualizing his function and role as the headmaster of the madrasa, including educators, managers, administrators, supervisors, leaders, innovators, motivators, and entrepreneurship, and this is in accordance with [11] [48] [49] [42] [3]. The madrasa head has a great responsibility in planning, organizing, fostering, implementing and controlling madrasa and the human resources in it (Kum, Dantes, \& Sunu, nd), including Islamic religious education teachers (al-Quran Hadith, aqeedah, fiqh, SKI, kalam subject, and Arabic). Islamic Religious Education Teachers (PAI) as a driving force in guiding and fostering students especially in terms of moral cultivation [17].

Islamic Routines in Growing Social Behavior Students' core experience. The core routine is repetition. If every teacher enters the class to say hello, it can be interpreted as a routine effort. If students enter the class not saying hello then the teacher reminds them that when they enter the class they should say greetings, this is also one way of getting used to religious behavior). Look at the routine carried out by the Messenger of Allah [8], pay attention to parents when educating their children. Children are accustomed to getting up early, getting up early as a habit that will affect their lives. In doing other work he tends early in the morning, even as early as possible. People who are usually clean will have a clean attitude; he is also clean in heart, clean in mind. The educational experts agreed to justify the habit as one of the efforts of good education in the formation of adult humans [46].

The routine method is very good to use because what we are accustomed to is usually good and right, we shouldn't get children used to do. This needs to be realized by the teacher because the teacher's behavior repeatedly, even if done playfully, will influence students to get used to the behavior. The routine method goes hand in hand with the exemplary method because the routine is exemplified by the teacher [36] [33]. Routines can be done in any environment, whether in the madrasa, at home, or in the community. Madrasa as one of the formal educational institutions has an important role in the process of shaping student behavior because routines in madrasa will be able to run optimally if supported by appropriate regulations and supervision methods [13]. In the process of implementation if there are students who pay less attention to religious aspects and even the reality of students' social behavior that does not reflect existing norms in religion, then new methods of routine and supervision emerge to deal with these problems [1], so they can really produce students who have high moral standards and have high-quality education.

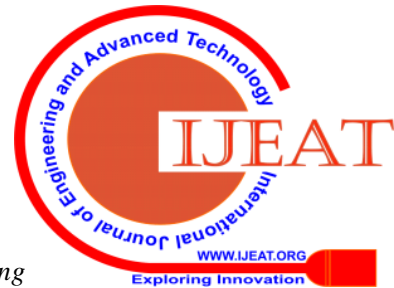
\& Sciences Publication 


\section{Islamic Habituation in Growing Students' Social Behavior}

The declining morality of the Indonesian people is caused by an important aspect missing in the education system, namely the routine aspect. This aspect is very important in transferring knowledge into the minds of the people such as honesty, fairness, and humility because these values cannot be given an assessment through someone's notification [43]. Good values or norms must be accustomed from an early age through a continuous and continuous routine because this will be able to shape the attitudes, personality, or behavior of children/students in their growth. Parents and teachers assume a great responsibility in instilling or accustoming religious activities to foster social behavior in students in the life of the nation and state, especially in the madrasa environment [30] [12] [24].

\section{THEORY REVIEW}

Islamic routines are also called religious routines or also called religious activities. Activities are acts of habituation carried out by someone in daily life in the form of words, deeds or other [28]. So the meaning of religious activities is all activities originating from religious values that are believed to prevent damage or instability in everyday life. Religious activities are activities related to religion that exist in daily life to accustom students to think, behave, and act in accordance with Islamic religious guidance [5].

Cultivating social behavior according to [34] [35] is an attempt to teach individuals about how to speak, how to behave, and give love continuously and to create individual characteristics. The right words in communicating can create a personal identity. In this regard, social interaction learning can also guide students to have better mental power and more acceptable emotional health by developing confidence and realistic feelings and fostering empathy for others [4].

Efforts to foster the social behavior of students in MAN Rejang Lebong are inseparable from the role of the principal and teachers in MAN Rejang Lebong by organizing management or management in order to achieve changes in student behavior. In this case, the principal uses management theory that is the process of planning, organizing, leadership and controlling the efforts of organizational members and the use of all organizational resources to achieve the stated goals [37]. Habituation of Islam in education is very important as found in research [18] that says that habituation of Islam is very important in growing student character [47].

[41] management as a process that distinguishes between planning, organizing, mobilizing, implementing and controlling, by utilizing both science and art, in order to be able to accomplish the goals set previously. [21] defines management as a process of planning, organizing, coordinating, and controlling resources to achieve goals effectively and efficiently [14]. Effective means that the objectives can be achieved in accordance with planning, while efficient means that the task is carried out correctly, organized, and according to schedule. Management is the achievement of goals that are set in advance by using the activities of others. Management or management in the general sense according to [39] is the administration, regulation, or arrangement of activity. The headmaster is derived from two words namely headmaster and madrasa. The word head can mean the chairman or leader in an organization or an institution. And madrasa is an institution that is a place to learn and receive lessons. Thus the headmaster can be defined as a functional teacher who is given the task to lead a madrasa where teaching and learning processes are held, or where interaction occurs between the teacher giving the lesson and the student receiving the lesson. The madrasa head is a leadership position that cannot be occupied by people without being based on considerations. Whoever will be appointed as head of the madrasa must be determined through certain procedures and requirements such as educational background, experience, age, rank, and integrity [2] [31].

The headmaster should have ability on influencing, guiding, coordinating and mobilizing other people who are related to the development of education and the implementation of education and learning [27] [45]. The word routine comes from a word ordinary so that it becomes a routine means to get used to something that is good [25] [8] [37]. There are routines that mean doing repetitive work so naturally, such as you can do it right [31]. While the word religion comes from the basic word religion which means the nature contained in religion. According to [5], religion can also mean a system of norms or rules governing relations among humans one another and with the other nature in accordance with the faith and the observance of religious duties [5] [6].

Routine religious activities can be interpreted to accustom continuously or repeatedly to students to do things that contain norms or rules that govern the relationship between humans and humans, humans with nature, and humans with God. The forms of routine religious activities referred to as; reciting prayers before learning, reading short verses of $\mathrm{Al}$ Quran, sholat dhuha, collecting charity and cleaning in Friday, sholat dhuhr, reading prayers, 5S (senyum, salam, sapa, sopan, santun), and other religious extracurricular activities to foster the character of love to God as explained in the research results of [23]. Behavior is the response or reaction of individuals manifested in movements (attitudes), not just bodies or speech. The word social comes from the Latin word socius which means as a friend, social is also interpreted to relate to society [40]. [49] explain that social behavior religion can be defined as individual student attitudes or reactions in dealing with the components of madrasa personnel that grow because of the regular and continuous routine of religious activities. Others are highly disciplined, honest, helpful, sympathetic, and friendly [28].

\section{RESEARCH METHODS}

This research uses a case study approach with qualitative methods [16], which interviews are used. The data that was looked for is about the routine of Islam in the growing social behavior of students. It was analyzed by using a sociological approach [15] because it is directly related to the symptoms that appear around the organized human environment informal education units, namely Madrasa. Similar to that [34], mention that a humanistic approach is used in qualitative research in understanding the social realities of idealists who focused on a view of social life. The qualitative paradigm views the social life as creativity among individuals [44]. 
This field research in which the data collection is carried out in the field with the location of MAN Rejang Lebong whose purpose is to conduct observations of a phenomenon in a natural state in the Madrasa [26]. Sources of data in this research are subjects from which data can be obtained [39]. The main data sources according to Lofland in qualitative research are words and actions, while written data, photographs, statistics, documents are additional data [26]. The data sources used by researchers as research subjects are Primary Data that is the first data obtained from the main subject. a) Primary data in this study are the results of observations and interviews on the routine process of religious activities. This data is used as the first data taken by researchers, to obtain maximum results. Based on the focus of the research, the sources of data in this study are: Head of MAN Rejang Lebong, Teacher of Islamic Religious Education (Aqidah-ahlak, Fiqh, Alqur`an Hadith, SKI, Arabic) at MAN Rejang Lebong, Grade XII Students Religion and other class students and the members of OSIS MAN Rejang Lebong, and the other subjects involved in the routine process of religious activities in MAN Rejang Lebong. b) Secondary Data is a data source that helps provide information or supplementary data as a comparison. In this case, secondary data is obtained from documentation data such as Islamic Education Books (Aqeedah-ahlak, Fiqh, Al-Qur'an Hadith, SKI, kalam subject and Arabic), Syllabus, RPP, Journal, and others.

The authors use the following method to complete the method of data collection: a). Observation, by using the observation method, the writer records events in situations related to proportional knowledge or the knowledge that is obtained from the data directly; b). Interview, Interview is a conversation conducted between the interviewer who asks a question while the interviewee is giving an answer to the question asked. This interview was submitted to the headmaster of the madrasa, the teacher who is an adviser of religious activities and students as the subjects of MAN Rejang Lebong; c). Documentation, the documentation method is used to obtain document notes or other agendas. This method is used to obtain data about the state of the teacher, the state of students, infrastructure and tools of teacher learning and student learning outcomes.

\section{RESULTS AND DISCUSSION}

\section{Religious Routines of MAN Rejang Lebong Students}

Habituation aims to foster students' social behavior to form noble human beings as explained in the results of [22] in the implementation of madrasa head using POAC theory, in the results of research conducted by [9] [10] [34] that the implementation of the Management study is as follow. Planning, policy or tips or steps taken by the madrasa head in the routines of diversity activities and fostering the social and religious behavior of the madrasa students so that they can run smoothly and effectively according to the observations of the researchers as follows; a) Establish a special order for madrasa about the time to carry out routine religious activities, especially the schedule for entering the first hour of activity starting at $07.15 \mathrm{WIB}$, in addition to the existing madrasa rules; b) Making a plan for religious activities together with the teacher; Organizing, create the policies with a). Directly appoint the deputy head of the student madrasa as a coordinator to oversee every activity involving students, especially religious activities. b) Appoint teachers to guide religious activities to accompany, guide and develop the students in performing the religious activities, c) Arrange a schedule of religious activities together with the deputy head of the madrasa and the supervisor of religious activities; Actuating; Instruct directly or indirectly to students to comply with the rules of madrasa, especially madrasa admission hours: a) Explain directly or indirectly to students about punishments for students who violate the rules of madrasa; b) Give punishments directly to students who violate the rules of madrasa especially those who do not participate in religious activities without any good reason, c) Following the religious activities, for example, become an imam of sholat dhuha and dhuhur, lead in reading salawat and become the preacher or the speaker in commemoration of the religious days.
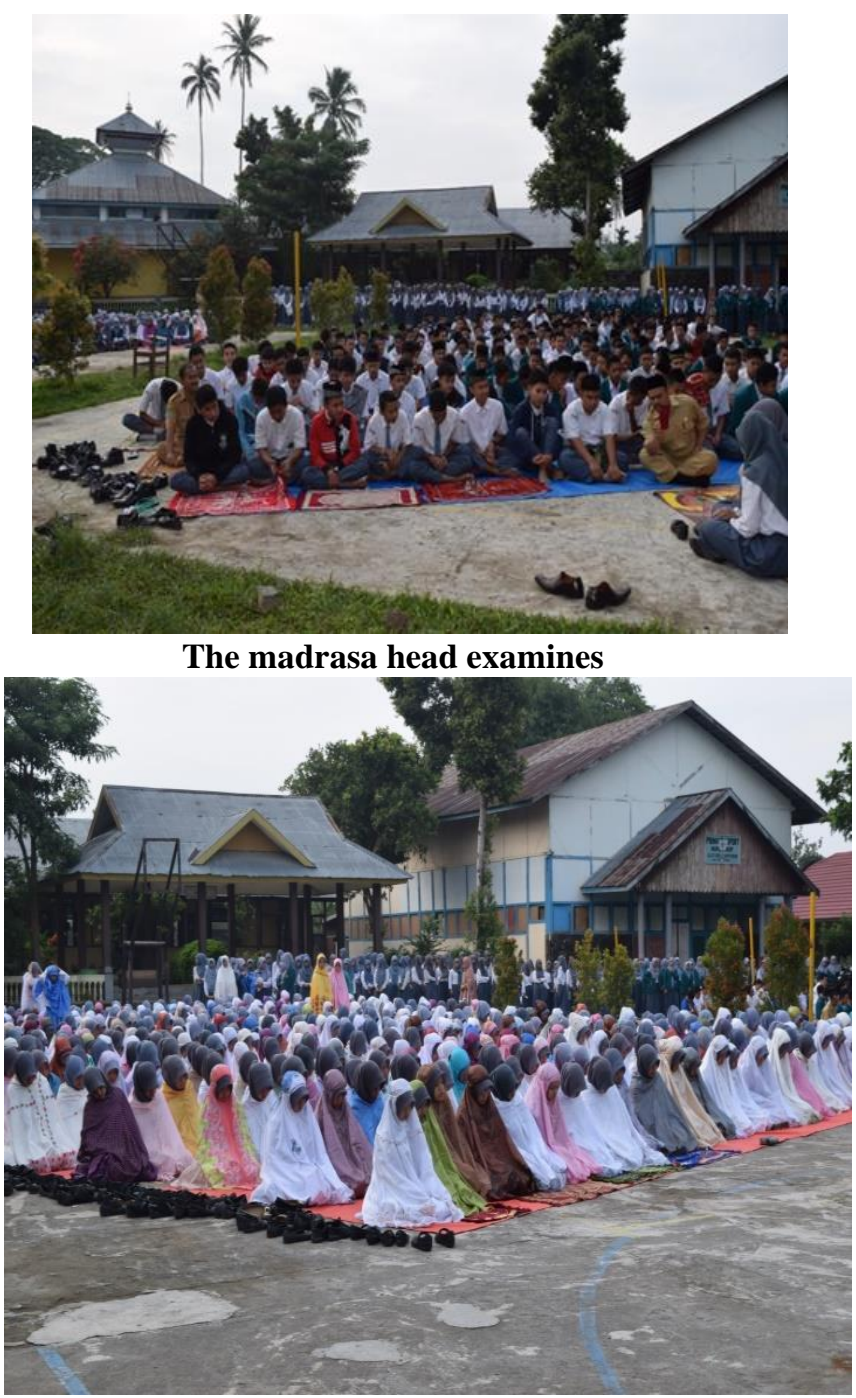

the memorization of juz 'amma

Praying dhuha in the field
Published By:

Blue Eyes Intelligence Engineering \& Sciences Publication 


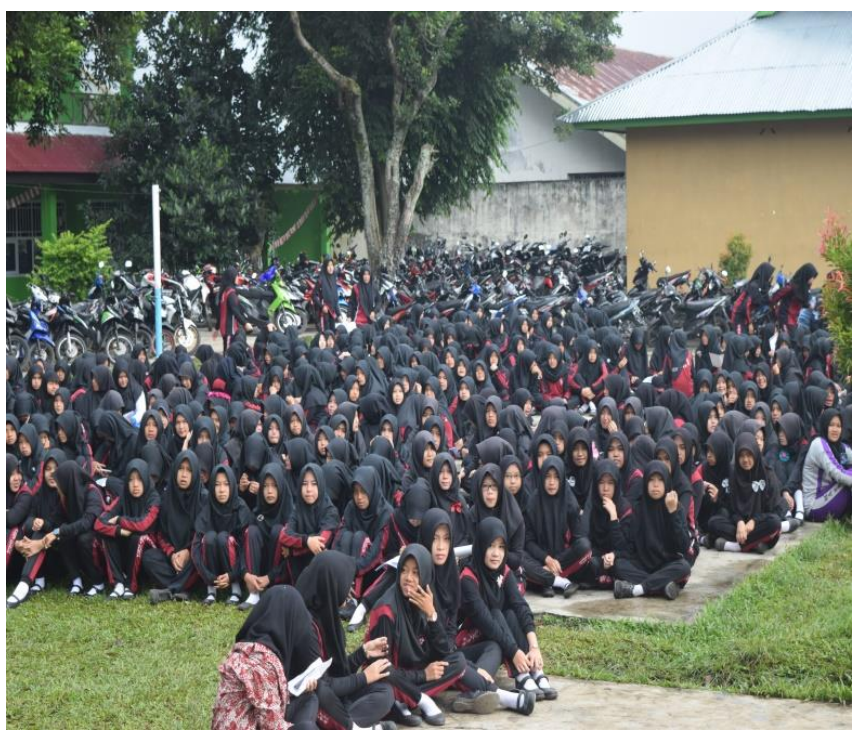

Students follow the muhadarah in the field

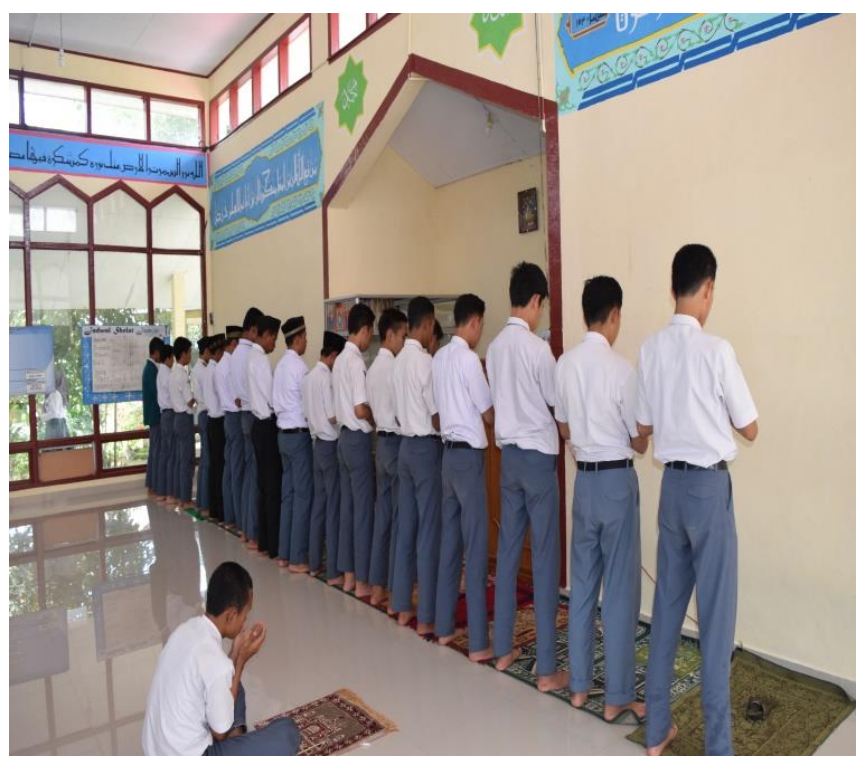

Praying Dhuhr in the mosque

The following are the results of observations that researchers have done, record and classify: 1) Reading the verses of the Qur'an, the verses means some verses in the Quran that is recited from juz 1 to juz 30 which is led by the chairman class or guided by one student; 2) Reading Prayers, it means the opening and closing prayers of learning activities; 3) Reading Asmaulhusna; 4) Asmaulhusna who is accustomed to reading by students are the good names of Allah with 99 names; 5) Dhuha, Sholat Dhuha followed by all students held in the field every Tuesday, Wednesday, Thursday and Thursday; 6) Sholat Dhuhur, this is followed by all students of MAN Rejang Lebong which is held in the madrasa mosque from Monday to Saturday except Friday; 7) Friday Prayer or Sholat Jumuah that is required for boys of MAN Rejang Lebong students every Friday located at the MAN mosque; 8) Reciting whole Quran in every the second week for 6 days in the month of Ramadan. The adviser of religious activity gathers 30 students to read the Quran which is each student read 1 juz, so that every day can recite the Quran 30 juz; 9) Pesantren kilat at the beginning of Ramadan that all students took part in the flash pesantren by involving Kemenag of Rejang Lebong and Rejang Lebong Regional Police as the informant; 10). Speech of Friday morning/muhadarah. After implementing morning gymnastics on Friday all students sit on the field to take part in the Friday morning tausiyah activities, which follow in the speech event are representatives of the class according to the schedule that was made; 11). 5S habituation includes; a) Smile (Senyum), it means that students are accustomed to smiling as a sign that Muslims have a suave nature, not to frown as a sign of hatred of the people they met. The words delivered with a sincere smile sounds better to hear than with a cruel and curt face; b) Regards (Salam), meaning that in addition to smiling students are accustomed to always greet the people they meet and answering greetings from those who say hello to him; c). Greet (Sapa), which means greeting with words, waving of hands, facial expressions and nodding of the head; d). Well mannered (Sopan), means that students are accustomed to having a good manner in getting along that respect to the older and the younger; e). Polite (Santun), it means students are accustomed to always speak soft and soothing words so that the people around them like it; b) Charity Friday and Clean Friday; 1) Charity Friday means routine for students to issue infaq or collect the money into social funds 2) Clean Friday means routine for students to always show personal and environmental hygiene with active work; c) Incidental Religious Activities: 1) Recitation of Istighatsah/dhikr; 2) Commemoration of Islamic Holidays; 3) Halal bihalal; 4) Safari Friday; 5) Ta zziyah; 6) Istisqa prayer; Controlling, the headmaster must: a). Oversee the social behavior of students inside and outside the school; b). Do an analysis of student learning outcomes; c). Request reports from students' parents.

\section{Constraints faced by the Head of Madrasa}

The problems of religious routine activities in MAN Rejang Lebong, namely: 1) Inactivity of some students in participating the religious activities in MAN Rejang Lebong due to lack of motivation in students and activities that are packaged less interesting; 2) The implementation of Sholat Dhuha in the field when it rains, then sholat dhuha is diverted at the mosque; 3) Sholat Dhuha is held at 07.15 WIB so that students who are late cannot attend the Sholat Dhuha activities in the field; 4) Lack of awareness for teachers to take part in the Sholat Dhuha activities in the field; 5) When starting the lesson at the first hour begins by reading the verses of the Qoran, salawat and recitation of Asmaul Husna which should be guided by the teacher who teaches at the first hour but teachers who teach at the first hour are often late in class; 6) Lack of means for performing wudhu' when going to perform Sholat Dhuhur; 7) Often late gymnastics activities begin on Friday morning so that the pilgrimage every Friday is not sufficient; 8) Lack of awareness from students; 9) The influence of Internet shows, television, and also other social media.

\section{CONCLUSION}

Based on the theoretical analysis of the findings data, the following conclusions can be drawn from the Management of the Madrasa Head in a Religious Routine to foster social concerns in MAN Rejang Lebong students. 
Planning is to make a special order for madrasa about the time to carry out routine religious activities, especially the schedule for entering the first hour of the activity starting at 07.15 WIB, in addition to the existing madrasa rules and making plans for religious activities together with the teacher. Organizing, namely appointing the deputy head of the madrasa in the field of student affairs as a coordinator to oversee every activity that involves students, especially religious activities, appointing teachers to guide religious activities to assist, guide and foster students in carrying out religious activities, and arrange a schedule of religious activities together with representatives madrasa head and coach of religious activities. Actuating is instructing directly or indirectly to students to comply with the rules of madrasa especially the hours of admission to madrasa, explain directly or indirectly to students about the punishments for students who violate the rules of madrasa, give punishments directly to students who violate the discipline of Madrasa, especially those who do not participate in religious activities without a good reason, and involve themselves in religious activities, for example become imam in sholat dhuha and sholat dhuhur, lead reading salawat and become preachers or speakers in commemoration of religious holidays. Controlling is supervising directly or indirectly the implementation of religious activities in the field, requesting reports from relevant subjects in religious activities to find out the effectiveness of the implementation of these activities as an evaluation step, and discussing the results of these religious activities with teachers in monthly routine meetings as a step evaluation and to determine the routine program of religious activities in the next time.

\section{ACKNOWLEDGMENT}

We would like to express our special thanks and gratitude to our rector IAIN Curup (Dr. Rahmad Hidayat, M.Ag., M.Pd) dean of Faculty Education Universitas Bengkulu (Prof. Dr. Sudarwan Danim, M.Pd.) and Coordinator Study Program Doctor of Education, Universitas Bengkulu (Prof. Dr. Wachidi, M.Pd.) who gave us the support to do this wonderful project. Secondly, we would also like to thank our lecturer (Dr. Muhammad Kristiawan, M.Pd.) who helped us a lot in finalizing this project within the limited time frame.

\section{REFERENCES}

1. Ahmad, R., Ansori, M., \& Ibnu, S. (2016). Strategi Penanaman Nilai-Nilai Pendidikan Islam Pada Peserta Didik [Strategies for Implementing Islamic Education Values in Students]. Malang, UNM Press.

2. Andriani, S., Kesumawati, N., \& Kristiawan, M. (2018). The Influence of the Transformational Leadership and Work Motivation on Teachers Performance. International Journal of Scientific \& Technology Research, 7(7).

3. Apriana, D., Kristiawan, M., \& Wardiah, D. (2019). Headmaster's Competency In Preparing Vocational School Students For Entrepreneurship. International Journal of Scientific \& Technology Research, 8(8).

4. El Iq Bali, M. M. (2017). Model Interaksi Sosial Dalam Mengelaborasi Keterampilan Sosial [Social Interaction Model in Elaborating Social Skills]. Jurnal Pedagogik, 04(02), 211-277.

5. Endang Saifudin Anshari, (2004). Kawasan dan Wawasan Islam: Pokok-Pokok Pikiran tentang Paradigma dan system Islam [Islamic Regions and Insights: Principles of Thoughts about Islamic Paradigms and Systems]. Jakarta: Gema Insani.
6. Rahendra Maya. (2003). Esensi guru dalam visi-misi pendidikan karakter [The essence of the teacher in the vision-mission of character education]. Abstraks.

7. Fathurrochman, I., Budiman, D. A., Alamsyahril, \& Kristiawan, M. (2019). Revitalization Management of Islamic Boarding School Preventing The Radicalism. Restaurant Business, (10), 495-505. Retrieved https://journals.eduindex.org/index.php/rb/article/view/9462

8. Fathurrochman, I. (2017). Implementasi Manajemen Kurikulum Dalam Upaya Meningkatkan Mutu Santri Pondok Pesantren Hidayatullah/Panti Asuhan Anak Soleh Curup [Implementation Of Curriculum Management An Effort To Improve The Quality Of Hidayatullah Islamic Boarding School]. Tadbir : Jurnal Studi Manajemen Pendidikan, 1(1), 85-104.

9. Fathurrochman, I. (2017). Pengembangan kompetensi pegawai aparatur sipil negara (ASN) Sekolah Tinggi Agama Islam Negeri (STAIN) Curup [The development of the competency of the state civil servant (ASN) STAIN Curup]. Manajer Pendidikan, 11(21), 120-129.

10. Fathurrochman, I., \& Apriani, E. (2017). Pendidikan Karakter Prespektif Pendidikan Islam Dalam Upaya Deradikalisasi Paham Radikal [Education Character Of Prespective Islamic Education In The Effort Of Radical Traditionalization]. POTENSIA: Jurnal Kependidikan Islam, 3(1), 122-142.

11. Fitrah, M. (2017). Peran Kepala Sekolah Dalam Meningkatkan Mutu Pendidikan [The Role of the Principal in Improving the Quality of Education]. Jurnal Penjaminan Mutu, 3(1), 31.

12. Fitria, H., Kristiawan, M., \& Rasyid, A. (2019). The Educational Character on Instruction. Opcion, Ano 35, Especial No. 21 (2019) 964-979

13. Haningsih, S. (2008). Peran Strategis Pesantren, Madrasah dan Sekolah Islam di Indonesia [The Strategic Role of Isl amic Boarding Schools, Madrasa and Islamic Schools in Indonesia]. Surakarta, CV. Studi Pustaka.

14. Hermawan, R. (2010). Pengembangan Sumber Daya Sekolah [School Resource Development]. Jurnal Pendidikan Dasar, 12, 1-17.

15. Ida Zahara Adibah. (2017). Pendekatan sosiologis dalam studi islam (berindeks) [Sociological approach in Islamic studies (indexed)]. Jurnal Inspirasi, 1(1), 1-20.

16. Irmayani, H., Wardiah, D., \& Kristiawan, M. (2018). The Strategy of SD Pusri In Improving Educational Quality. International Journal of Scientific \& Technology Research, 7(7).

17. Khodijah, N. (2013). Kinerja Guru Madrasah Dan Guru Pendidikan Agama Islam Pasca Sertifikasi Di Sumatera Selatan [The Performance of Madrasah Teachers and Post-Certification Islamic Religious Education Teachers in South Sumatra]. Jurnal Cakrawala Pendidikan, 5(1), 91-102. https://doi.org/10.21831/cp.v5i1.1263

18. Khotidjah, S., \& Izzah, H. (2015). Islamic Habituation Sebagai Upaya Pembentukan Anak Usia Dini [Islamic Habituation As an Effort to Form Early Childhood]. PG-PAUD Trunojoyo, 2(2)

19. Kompas.com, 09 September 2019

20. Kompas.com 14 December 2018

21. Kristiawan, M., \& Ahmad, S. (2017). Desain pembelajaran sma plus negeri 2 banyuasin III berbasis karakter di era masyarakat ekonomi asean [The design of high school learning plus state 2 banyuasin iii character-based in the era of the ASEAN economic community]. Jurnal Kajian Ilmu Pendidikan, 2(2), 403-432.

22. Kristiawan, M. (2016). Telaah Revolusi Mental dan Pendidikan Karakter dalam Pembentukkan Sumber Daya Manusia Indonesia Yang Pandai dan Berakhlak Mulia [Study of the Mental Revolution and Character Education in the Formation of Clever and Noble Indonesian Human Resources].Ta'dib,18(1),13-25

23. Kristiawan, M., \& Fitria, H. (2018). Menumbuhkan Rasa Cinta Kepada Allah Dan Mahluknya Pada Anak Usia 5-6 Tahun [Fostering Love For God And His Creatures to The Children Aged 5-6 Years]. Thufula: Jurnal Inovasi Pendidikan Guru Raudhatul Athfal,6(2).

24. Kristiawan, M., Nizarani., \& Syamsidar. (2019). Role of School on Forming Character of Z-Generation Through Entrepreneurial Skills. International Journal of Scientific \& Technology Research, 8(10).

25. Kum, J., Dantes, N., \& Sunu, I. G. K. A. (n.d.). Organisasi dan Pemberian Insentif dengan Profesionalisme Guru Tidak Tetap SMA Negeri di Kota Denpasar [Organization and Provision of Incentives with the Professionalism of Non-Permanent Teachers in Public High Schools in Denpasar City] 


\section{Islamic Habituation in Growing Students' Social Behavior}

26. Lexy J. Moleong, (2008). Metodologi Penelitian Kualitatif [Qualitative Research Methodology]. Bandung: PT Remaja Rosda Karya.

27. Lian, B., Kristiawan, M., \& Fitriya, R. (2018). Giving Creativity Room to Students through the Friendly School's Program. International Journal of Scientific \& Technology Research, 7(7).

28. Maseleno, A., Ayshwary, B., Ivanova, T. N., Hashim, W., Nguyen, P. T., Shankar, K., Kristiawan, M., Huda, M. (2019). General Theoretical and Philosophical Aspects of Modern Education. Aspectos Teóricos y Filosóficos Generales de la Educación Moderna. Revista San Gregorio 2019, No. 32 Special Issues August

29. Media Indonesia 10 September 2019

30. Murdiono, M. (2010). Strategi internalisasi nilai-nilai moral religius dalam proses pembelajaran di perguruan tinggi [The strategy of internalizing religious moral values in the learning process in higher education]. Jurnal Cakrawala Pendidikan, XXIX(3), 99-111.

31. Renata, R., Wardiah, D., \& Kristiawan, M. (2018). The Influence of Headmaster's Supervision and Achievement Motivation on Effective Teachers. International Journal of Scientific \& Technology Research, 7(4).

32. Republika 07 September 2019

33. Ristianti, D. H. (2017). Analisis Hubungan Interpersonal Mahasiswa terhadap Dosen dalam Proses Bimbingan Skripsi [Analysis of Student Interpersonal Relationship to Lecturers in the Thesis Guidance Process] ISLAMIC COUNSELING: Jurnal Bimbingan Konseling Islam, 1(1) 25.

34. Ristianti, D. H. (2018). Konseling Islami Untuk Meningkatkan Efikasi Diri Pasien HIV/AIDS [Islamic Counseling To Improve the Self-Efficacy of HIV/AIDS Patients]. Indonesian Journal of Educational Counseling, 2(1), 113-130.

35. Ristianti, D. H., Sudarwan Danim, Hadi Winarto, I Wayan Dharmayana. (2019), The Development Of Group Counselling Assessment Instruments. International Journal of Scientific \& Technology Research, 8 (10).

36. Sarina., Kristiawan, M., \& Wardiah, D. (2019). Module Development the Utilization of Patchwork Fabric As Teaching Materials Crafts on the Subjects of Craft and Entrepreneurship For High School Students. International Journal of Scientific \& Technology Research, 8(5).

37. Shitsuke. Manajemen Gaya Jepang [Japanese Style Management]. http//equatornews.com/berita/index.asp? berita =etalase\&id=13137. diakses 12 Maret 2016.

38. Sindonews 05 September 2019

39. Suharsimi Arikunto, (2006). Prosedur Penelitian Suatu Pendekatan Praktik, [Research Procedure A Practical Approach]. Jakarta : Rineka Cipta.

40. Trisno Yuwono, (1994). Kamus Bahasa Indonesia Praktis [Practical Indonesian Dictionary]. Surabaya: Arloka.

41. Tobari., Kristiawan, M., \& Asvio, N. (2018). The Strategy of Headmaster on Upgrading Educational Quality In Asean Economic Community (AEC) Era. International Journal of Scientific \& Technology Research, 7(4).

42. Wandasari, Y., Kristiawan, M., \& Arafat, Y. (2019). Policy Evaluation of School's Literacy Movement on Improving Discipline of State High School Students. International Journal of Scientific \& Technology Research, 8(4).

43. Wulandari, Y., \& Kristiawan, M. (2017). Strategi Sekolah dalam Penguatan Pendidikan Karakter Bagi Siswa dengan Memaksimalkan Peran Orang Tua [School Strategies in Strengthening Character Education for Students by Maximizing the Role of Parents]. JMKSP (Jurnal Manajemen, Kepemimpinan, dan Supervisi Pendidikan), 2(2).

44. Yatim Riyanto, (2007). Metodologi Penelitian Pendidikan (kualitatif dan kuantitatif) [Educational Research Methodology [Qualitative And Quantitative].(Surabaya: Unesa University.

45. Yuliani, T., \& Kristiawan, M. (2017). Peran Kepemimpinan Kepala Sekolah dalam Membina Kompetensi Sosial (Pelayanan Prima) Tenaga Administrasi Sekolah [The Role of the Principal's Leadership in Fostering Social Competence (Excellent Service) School Administration Staff]. JMKSP (Jurnal Manajemen, Kepemimpinan, dan Supervisi Pendidikan), 1(2).

46. Zakki, F. M., (2019). Peran Pembiasaan Keislaman Terhadap Religiusitas Santri Kelas 7 Madrasah Tsanawiyah Pondok Pesantren Modern Islam Assalaam Sukoharjo [The Role of Islamic Habituation on the Religion of Santri Class 7 Madrasa Tsanawiyah Islamic Modern Islamic Boarding School Assalaam Sukoharjo]. Surakarta, CV. Studi Pustaka.

47. Sayer, I. M., Kristiawan, M., \& Agustina, M. (2018). Fairy Tale as a Medium for Children's Character Cooperation Building. Al-Ta lim Journal, 25(2), 108-116.

48. Khasanah, U., Kristiawan, M., \& Tobari. (2019). The Implementation of Principals' Academic Supervision In Improving Teachers'
Professionalism in the State Primary Schools. International Journal of Scientific \& Technology Research, 8(8)

49. Salwa., Kristiawan, M., \& Lian, B. (2019). The Effect of Academic Qualification, Work Experience and Work Motivation towards Primary School Principal Performance. International Journal of Scientific \& Technology Research, 8(8).

\section{AUTHORS PROFILE}

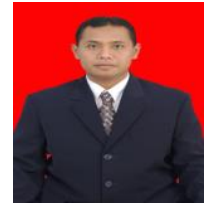

Baryanto is a lecturer who has an educational management background, currently serves as secretary of the State Institute of Islamic Studies (IAIN) Curup Institute for Research and Community Service (LPPM), he is a candidate of educational doctor at Bengkulu University.

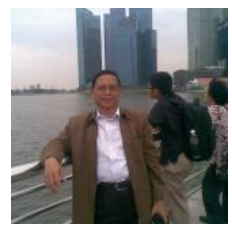

Syaiful Bahri is a lecturer at State Institute of Islamic Studies (IAIN) Curup, his current activity is actively organizing, the writer has served as Secretary of the Indonesian Ulama Council (MUI) and FKUB Secretary of Bengkulu City, he is a candidate of educational doctor at Bengkulu University.

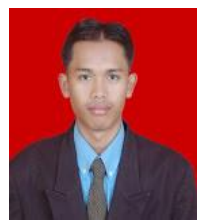

Irwan Fathurrochman is a lecturer who has an educational management background, the writer is very concerned in the field of writing scientific papers and has had several publications, he is a candidate of educational doctor at Bengkulu University, currently serving as Editor in Chief one of the journals at State Institute of Islamic Studies (IAIN) Curup.

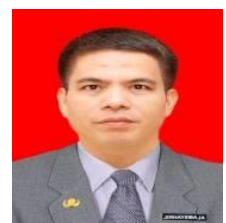

Alamsyahril, who has a language education background, is a widyaiswara ahli madya (senio trainer) at the Government of Lubuklinggau in South Sumatera. Currently, he is a candidate of educational doctor at Bengkulu University. 